\title{
PROGRAMMING OF URBAN REVITALIZATION
}

\author{
Tadeusz BILIŃSKI ${ }^{1}$ \\ University of Zielona Gora, Zielona Góra, Poland
}

\begin{abstract}
The planning stage of the investment-construction process is of a crucial importance. Its overall impact on the costs, construction time and the quality of design solutions is huge. However, in practice, little attention is given to this pre-design stage, except for public buildings or other buildings of particular importance. In consequence, the results of investment and construction activities are unsatisfactory. Therefore, the issue has been given careful consideration in this paper.

The paper discusses the issue of programming urban revitalization, emphasizing its socioeconomic importance. To illustrate the complexity of revitalization projects planning, the author draws attention to social, economic, technical and organisational factors, such as public participation, reorganization and revaluation of land use planning, rationalization of energy use, organization and management of revitalization processes, as well as technical progress. Summarising the paper, the author concludes that in order to improve the quality of life of town residents and to protect material national heritage, it is indispensable to continuously revitalize subsequent town areas.
\end{abstract}

Keywords: revitalization, importance, town renewal

\section{INTRODUCTION}

Today, both the purposefulness and the urgent need of intensive revitalization processes are increasingly frequently emphasised. It is claimed that they should be applied not only to selected areas, quarters of our towns, but also to whole residential estates and settlements. Backlogs are enormous. More and more areas of towns require immediate major overhauls, rapid adaptation to modern civilization requirements and to residents' current needs. Increasing delays

1 Corresponding author: University of Zielona Gora, Faculty of Building, Architecture and Environmental Engineering, Z. Szafrana st 1, 65-516 Zielona Góra, Poland, e-mail: t.bilinski@wp.pl, tel. +48683282477 
generate increasingly growing socio-economic loss (Fig. 1). All previous attempts to create a system of legal and financial support for urban regeneration did not produce results. However, individual regeneration activities, of a selective or limited scope, will not bring sufficient results. Renovation of individual buildings, often historic buildings, engineering structures, or fragments of urban technical and transport infrastructures, may be insufficient in solving the contemporary problems of our towns. In addition, all previous attempts to create a national program of urban regeneration, as well as the implementation of the financial system to support revitalization activities have not produced results, too. There are no rules, procedures or methods of organization of contemporary revitalization processes as well as no legal basis for the state to support the revitalization activities. Therefore, it is believed that the discussion on the issue of urban revitalization is fully justified and purposeful.

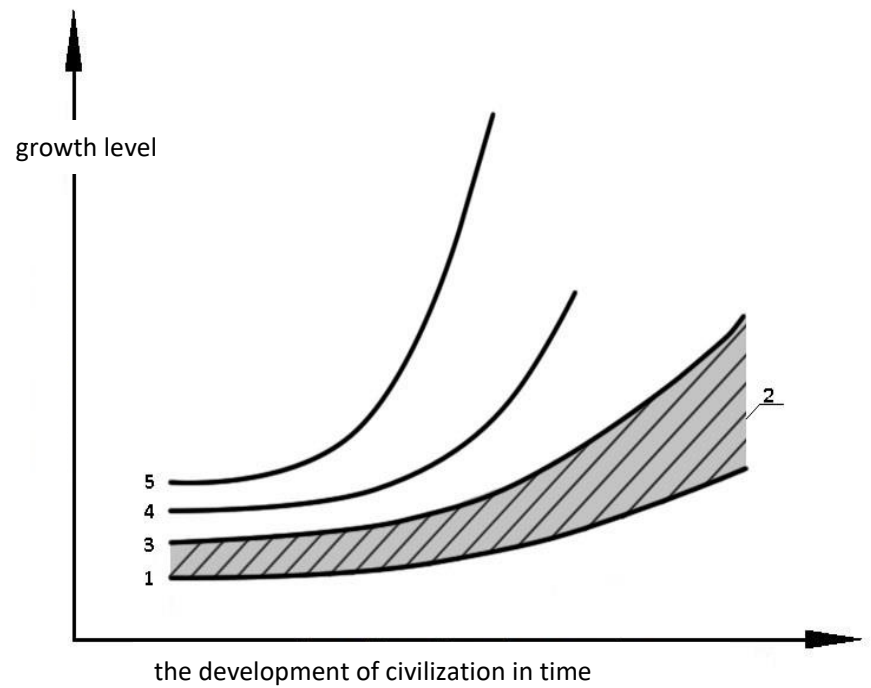

Fig. 1. Schematic growth in activities of urban areas revitalization: 1 - the actual level of revitalization, 2 - increase in revitalization backlogs, 3 - level of socio-economic revitalization, 4 - economically justified level of revitalization, 5 - level of social expectations

\section{REVITALISATION - TOWN RENEWAL}

Revitalization should be understood as comprehensive and organized investment and construction activities carried out in a specific, consistent area of a town. Revitalization projects are generally more complex processes than investment and construction projects since the latter ones are realised on undeveloped, greenfield areas which are usually free from any unexpected hindrances or impediments. 
Unlike new investments, the implementation of revitalization projects may encounter numerous unexpected difficulties, often arising from the essence of regeneration but also from careless and superficial diagnosis and preparation of the project.

In a general approach, [7] urban regeneration is a process of town adaptation to the current needs of local communities. The general objective of urban renewal is to ensure harmony and multilateral development by adapting old buildings to new needs, while preserving their cultural and historical values. Revitalization includes recultivation and modernisation of the area.

The material scope of revitalization of a specific area of a town is generally more extensive and diverse, compared to a normal investment activities. It covers a broad spectrum of legal, organizational, technical and social activities. Revitalization must also meet all the requirements for organized investment and construction activities. Otherwise, endless individual revitalization processes, continuously introduced changes, disruption into the schedule of construction and engineering works, ultimately lead to increased costs, delayed work, deteriorated quality of work and, what is also important, frequently to town malfunctioning and disorganization of residents' life. It should be remembered $[2,3,6]$ that the structure of the existing urban development consists of:

- spatial, surface and linear objects,

- historic buildings and buildings under conservation protection,

- objects in different technical condition and performed in different technologies,

- urban green areas: parks, squares, avenues,

- buildings fulfilling various functions: public buildings, residential buildings, religious buildings as well as industrial buildings.

Sometimes it is necessary to construct new transport facilities, or to rebuild the existing transport systems, or else, to return to old public transport means, i.e. suburban railways or modern low-noise tramways.

Revitalization may be an essential element in shaping the culture of modern society, and thus, in development of civil society. And not only through the consultation of investment projects, monitoring their implementation, but also through participation in the realisation of particular construction projects as part of public-private partnerships or concessions for works or services.

Revitalization should stimulate local community, be the impulse to the qualitative transformation of a town, its parts or districts, be the impulse to improve the quality of life, and to the develop civil society [5].

Revitalization has too freely been referred to as various overhaul and investment activities such as: repair of arbitrary fragments of urban areas, often very small, or referring to a particular type of buildings, e.g. a few buildings, front facades of buildings along a selected section of a street, or the renovation of just a part of 
technical or transport infrastructure. Also activities which are complex but carried out on a limited area are mistakenly called revitalization, although they do not have much or any impact on the functioning of, at least, a town quarter.

Only comprehensive, coherent, objective-oriented investment and construction activities carried out on a relatively large area of a town may be considered as revitalization of an urban area.

\section{PROGRAMMING OF CONSTRUCTION AND INVESTMENT PROJECTS}

In an investment and construction process (Fig. 2), it is particularly important to program any investment and construction ventures [5]. However, in construction practice, except for particularly important investments, little attention has been paid to the planning stage, which is generally limited to a superficial analysis. Instead, designers and engineers immediately go to the planning and designing stage just after the formulation of the design task. However, it is the planning of the investment which is the basis for the optimal solution to the design task, a solution which would meet the objectives of sustainable development and which would respect the architectural and organizational conditions. Planning is the first, frequently long-lasting step, of an investment and construction process. Therefore, it is a very important element in the investment and construction process, which should involve pre-design comprehensive and thorough studies and analyses [5], which would result in the determination of a number of methods of the project realisation [1], a number of ways and sources of financing as well as the determination of locations for new objects and the conditions of the investment realisation.

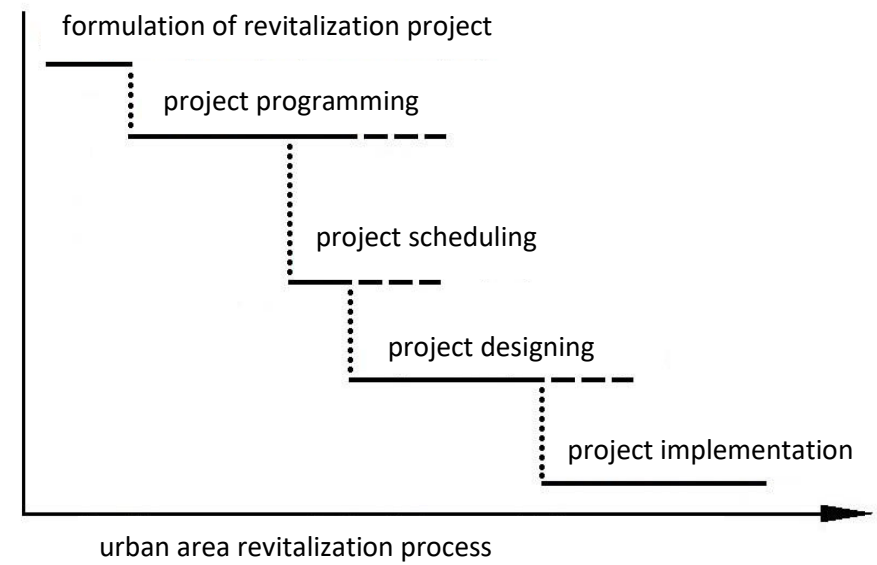

Fig. 2. Illustrative dependence of various stages of a revitalization process 
The scope of the analyses and considerations may obviously vary, depending on the type and size of the investment and construction project, its location and technical feasibility of its realisation. The considerations may refer to new buildings, but also to extension, redevelopment or renovation of existing buildings. But the considerations may also include suggestions, which of the considered concepts is most appropriate and most advantageous with regard to a particular criterion.

Generally, the elaborated program of the investment should include [4]:

- justification of the advisability of the investment and options for its implementation,

- an opinion of the planned location for the investment or the indication of suitable locations which comply with the local spacial development plan, or the study of conditions and directions of spatial development,

- determination of the material scope of the investment and the period of its realisation,

- information on the anticipated material effects,

- environmental impact assessment,

- economic effectiveness assessment,

- information on the possible completion of the entire investment (particular investment tasks) as well as on the construction equipment ensuring proper use of the constructed buildings in accordance with intended purpose.

- general information referring the planned investment costs at various stages of its realisation,

- planned total costs and the finance sources, the colloquially called "investment financial assembly,

- framework schedule of realisation

- possibility of developing the investment completed as scheduled, or, if necessary, in the proper order,

- providing ways to safeguard the interests of any third party,

- presenting possible consequences of the failure to comply with a determined deadline.

The deep and thorough studies within the investment planning stage should result in the determination of possibly most efficient design solution (Fig. 3) meeting the basic principles of sustainable development, and the justification of the advisability of the planned investment.

The result of the planning stage of an investment and construction project is the feasibility study of the investment, the primary objective of which is the justification for the cost-effectiveness of the proposed investment. This document should contain a number of reasons for the desirability of the investment such as: financing, market research, selection of technology, the environmental protection, improving safety, health conditions, and conditions of use. 


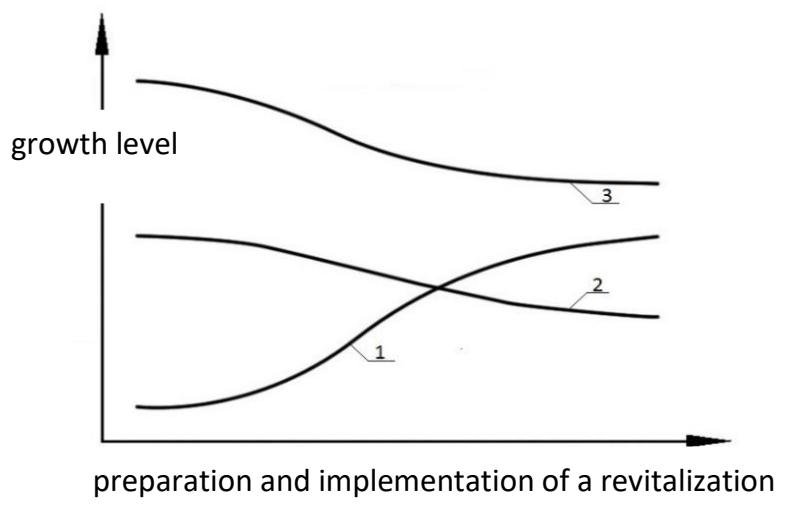

Fig. 3. Dependence of costs and time of revitalization projects on the intensity of planning: 1 - intensity of planning, 2 - work load in the design stage, 3 - costs and time of the realisation of revitalization projects

\section{REVITALIZATION PROJECTS PLANNING}

Planning urban revitalization projects involves a much wider range of studies and analyses than planning construction and investment projects. First of all, the chosen built-up area needs to be looked at in a broader context. It is the history of the town, its development strategy, culture and the standard of living of local society which should be given thorough consideration. Various revitalization issues need to be considered, not only in terms of current needs and requirements, but also, and perhaps above all, in terms of the functioning and development of the town in a long-time horizon [4], with a view to preserve or restore the consistency of the whole area of the town.

Space is a common good. Thus, its quality should be a common and absolute issue. However, it is observed that Polish towns suffer from growing chaos in spatial planning, growing architectural mess, uncontrolled suburban development resulting in a progressive spread of their borders ("urban sprawl"). The phenomenon is confirmed by numerous studies, documents and resolutions, including an open letter to the Prime Minister [11] sent recently by a group of academics, business and political activists. The lack of spatial order results in economic and social damage and affects the citizens' living standards. Thus, decisive action needs to be taken, not only in terms of planned investment activities but also taken revitalization projects. Revitalization activities may greatly reduce or even prevent careless development of suburban and urban areas. If revitalization of an isolated area of a town is to be completed successfully and the objectives are to be achieved at the scheduled time (with the possible fullest social acceptance and within economically justified costs), the plans of such a 
revitalization project should consider the whole range of social, sociological, economic, technical and organizational. To illustrate the complexity of urban revitalisation, a number of selected but important issues are discussed in the following subchapter.

\subsection{Public participation}

Public consultations are particularly important for the success of revitalization of urban areas. Opinions expressed by social organizations (housing associations, housing communities) as well as informal social groups or by individuals are particularly valuable. Local communities look at revitalization issues not only more specifically and thoroughly but also from a different perspective than professionals who, on the one hand, see the issue in a wider scale but on the other hand, they may misunderstand local conditions and implications. They evaluate solutions globally, while trinkets of local importance may elude them.

The implementation of local initiatives often brings many supralocal benefits, and often at much lower financial and material costs. Moreover, in such cases, social control of not only the realization stage, but also of the operation of new or reconstructed architectural and infrastructural solutions or transport systems is very effective. People tend to value and respect things more when they created them themselves or in cooperation, or even just with their consent.

One should also bear in mind that not everyone will equally be satisfied with the results of urban revitalization. Some individuals, or even whole social groups will express their dissatisfaction and even opposition, often unfounded. Where the discontent is justified, a form of compensation is indispensable. The interest of third parties need to be protected, just as in the case of investment projects. The compensation may be a more complicated problem due to the various forms of ownerships, often legally unregulated.

\subsection{Reorganization and restoration of spatial planning}

Revitalization of urban space is a difficult and complex process. The progressive disorganization of urban space, the chaos in its architecture resulting from illconsidered investments, devastation of land, its improper use - may lead to a loss of cohesion of the town, the loss of harmony and aesthetics of urban architecture, to transport problems, and even with time, to disfunction of socio-economic milieu as well as public administration. Such a process leads not only to economic but also social losses. Vigorous functional, operational and technical efforts are indispensable, and they should take account of changing legal and organizational conditions, as well as of constantly rising social expectations.

Any revitalization of urban space or its parts must be objective-oriented, and should be looked at from the point of view of social needs of local communities, and not vested interests of individuals or informal social groups. Revitalization of 
urban space must be tailored not only to the current needs of local communities, but also to the needs of future generations. Thus, generally, revitalization of urban space which conserves the existing architectural structure, or obsolete transport systems, inefficient technical infrastructure, traditional external connections, or which retains the existing boundaries of the town and its administrative division - turns out simply insufficient. Profound transformations of the structure of a revitalized part of a town are frequently indispensable and additionally, they need to be conducted on the basis of a modified street network, should include previously introduced changes in the use and division of the property.

Public space has always been an important factor in shaping social life, culture of people's behaviour and social relations. Therefore, its form and quality are so important. Obviously, also the immediate vicinity of public space, including buildings fulfilling various functions (together with their facades), also squares, roads, rail and water transport systems, as well as greenery and small architecture objects, is very important.

Greeneries play a special role in public space. They include: parks, squares, avenues, local clusters of greenery and urban aquatic environments such as rivers, backwaters, ponds, streams and bathing waters. All these facilities form an urban landscape and fulfil recreation and leisure functions. Special zones, such as quiet zones, games zones, relaxation zones, etc., may be isolated within large areas of wild nature.

In the revitalization process, special attention should be paid to the greenery restoration, the reparation of ecological corridors and/or the incorporation of greenery into urban areas.

Revitalization of an urban area should restore its consistency or, if originally there was no consistency, should strive towards its formation. Obviously, areas fulfilling special functions of the town should be clearly separated one from another, but urban space should not be crisscrossed with fences, as they often hinder residents' lives.

Planning the reorganization of land-use one should constantly remember that the intensive development of the country will always depend on the energy efficiency, of the energy balance and national income. Thus, long-term plans aimed at reducing energy consumption are indispensable across the economy, and should be included within the plans of spatial development of the country. Since not only the development of selected modern industries, or the construction of low-energy buildings, or else the introduction of new energy-efficient means of transport constitute a sufficient scope of actions to significantly reduce energy balance. There is an urgent need for full renovation (technical and in terms of energy efficiency) of operated buildings, also for comprehensive modernization of transport systems and technical infrastructure, including transfer of thermal energy. 
The Municipal Energetic Audits (MEA) ${ }^{2}$, should serve as an indicator of the scope and intensity of actions. In a modified form, MEA expresses an opinion (evaluation) of the realised investments [8,9], as well as organizational and formal actions leading to the rational use of energy in a town.

Revitalization of an urban area should equip the town with modern networks of intelligent installations. It should provide:

- access to telecommunication services, in particular broadband Internet access

- a system of video cameras, in particular in transport networks and pedestrian passageways,

- integrated system for urban traffic management,

- should lead to the silencing of the town (point 4.5).

While reorganization of urban space, particular attention should be given to public transport and to the entire transport network of a town, in particular to its sensitive nods. It is vital to ensure the traffic flow and to increase the capacity of transport systems. The basic premise should be the adoption of the principle of public transport priority over individual transport and the introduction of an integrated system of traffic management. System TRISTAR, which covers Tricity (pt. 4.5), is a good example of a modern transport solution.

\subsection{Rationalization of energy use}

Obviously, in any programming of revitalization of an urban area, insightful studies on the rational use of energy must not be missed. The rational use can be measured by the Municipal Energy Audits [8]. However, its global recognition is not so simple. It depends on many factors, to mention a few: on the type of architecture and its dispersion, on thermal insulation of buildings and their technical condition, municipal lighting system, traffic control systems, etc. Today, the problem is significantly important, not only for socio-economic reasons, but also because of the necessity to meet the current and foreseeable requirements of the permissible energy demand of buildings, which will gradually change until 2021. The current level of acceptable energy consumption for singlefamily dwellings, amounting $120 \mathrm{~kW} / \mathrm{m}^{2} /$ year, will fall down to the level of $70 \mathrm{~kW} / \mathrm{m}^{2} /$ year. This does not apply to new buildings exclusively, but also the ones which have long been in operation, including buildings with previously mounted thermal insulation.

The aim of building renovation and the modernization of built environments is also reducing the energy consumption of urban agglomerations. Constructed and modernized buildings, according to the new regulations [7], will have to meet stringent requirements concerning the acceptable values of indicator Ep (the primary energy supply) and a minimum insulation of the building envelope. Until

\footnotetext{
${ }^{2}$ Assumptions, charts and rules for MEA are presented in [9]
} 
now, it was sufficient to satisfy one of the above criteria. Now, since the beginning of 2014, the applicable law has imposed many requirements which are to be met, e.g.: insulation of the envelope, the efficiency of the heating and ventilation systems. It is essential to include all the factors that affect the overall energy balance in the energy performance of a building [9].

Attention should also be paid, within the revitalization process, to any possibilities of using renewable energy sources, in particular solar energy (photovoltaic cells, solar collectors) and thermal energy of the earth (shallow and deep installations).

\subsection{Organization and management of revitalization processes}

Economic and social effectiveness is conditioned by a number of factors. We put much effort into the programming of revitalization scope and the determination of its particular tasks, while paying little attention to the organization of the entire project and the management of its processes. However, it is advisable to carry out a thorough analysis of the structure and conditions of the implementation of an entire revitalization project, since it is carried out on a large and heterogeneous area (access to the areas and buildings may be very limited) over a long period of time (multiannual cycle of realisation), includes a wide scope of construction and engineering works as well as various specialized work, involves a large number of participants (investors and owners). It is essential to develop a multi-optional plan of the organization and management of the entire project, assuming a high level of flexibility. Otherwise, the realisation will not be timely and qualitatively good, and in extreme cases can bring very large losses.

Of particular importance, in the revitalization work schedule, is to synchronize construction works, road works as well as specialised works. Determining the proper order and scope of work conditions the cost and, above all, the completion date of the entire project.

The management of an investment and construction process is conditioned by a number of acts, laws and regulations ${ }^{3}$.

\footnotetext{
3 allocating land for specific purposes and establishing the rules for land use and architecture Law on Spatial Planning and Development,

- conditions of locating buildings - regulation on technical conditions to be met by buildings and their location,

- standardization of activities involving the design and demolition issues - Construction Law,

- sharing information about the environment and its protection, issuing a decision on the assessment of the environmental impact - the Law on access to information on the environment and its protection, public participation in environmental protection and environmental impact assessments, - general and specific conditions of individual contracts binding the participants of the investment process - the Civil Code,

- rules for the selection of contractors - Public Procurement Law.
} 


\subsection{Technological change}

Taking account of technical progress in the planning of revitalisation projects is apparent. As is the inclusion of new generation technologies, building materials, new systems of organization and management of construction processes. But the planning process should take into account anticipated prototyped solutions that has already been implemented. The realisation of revitalization projects may lasts for many years. We already have examples of revitalization of small urban quarters which last even a dozen of years. Thus, planning needs to be not only forward-looking, but also to be a continuous process, occurring not only in the design stage, but also, during subsequent revitalization tasks (Fig. 2).

Referring to the reorganization and revitalisation of an urban space, it will be justified to present a modern technical solution - TRISTAR - an integrated traffic management system in the area of Gdańsk Gdynia and Sopot, as a good example of purposefulness of carrying out even profound changes in an urban structure.

The system includes:

- a public transport monitoring system, including monitoring and control of the movement of vehicles as well as information for passengers about transportation services,

- urban traffic management system, including traffic control, traffic safety management, access control and parking management, traffic information.

- The system ${ }^{4}$ includes 141 crosswords (Gdańsk - 67, Gdynia - 60, Sopot - 14), 108 video cameras and 60 speed cameras.

\section{CONCLUSIONS}

To improve the quality of life of town residents and to protect the national heritage, it is indispensable to continuously revitalize subsequent urban areas. To ensure rational and socially and economically justified revitalization, it is essential to program the revitalisation activities. Thus, it is indispensable to perform profound and insightful pre-design studies are essential.

The current effects of revitalization of our towns are insufficient (with the exception of building thermal insulation). The current revitalization processes, mostly conducted on small areas, are generally implemented over a very long period of time and are economically ineffective. However, spectacular, inconsiderable but purposeful actions do not solve anything. Backlogs in revitalisation are continuously increasing. (Fig. 1). In the future, the costs of adapting our towns to modern civilization demands may exceed the capacity of the state and the society. One can never compensate the loss of time. Thus, the

${ }^{4}$ Commisioned by Gdynia, Sopot and Gdańsk Town Halls, and developed by a team led by Dr. Eng. Kazimierz Jamroz. 
problem of urban revitalisation should be a strategic objective of the state policy and should be solved in a systemic and systematic way.

\section{REFERENCES}

1. Biliński T.: Heuristic approach to the revitalization of urban areas. Innovation in building engineering: proceedings of the INTERREGS IIIC 3CIP conference. Zielona Góra, 2005, Oficyna Wydawnicza Uniwersytetu Zielonogórskiego 2005, s. 25-38.

2. Biliński T.: Problemy rewitalizacji miejskiej infrastruktury drogowej. Przegląd Budowlany, nr 3, 2013.

3. Biliński T.: Renowacja i modernizacja społecznie ważnych fragmentów terenów miejskich. Przegląd Budowlany, nr 3, 2011.

4. Biliński T.: Rewitalizacja przestrzeni miast - wymóg współczesności. Wiadomości Projektanta Budownictwa, nr 6, 2010, s. 18-19.

5. Biliński T.: Struktura i uwarunkowania wspótczesnego procesu inwestycyjnobudowlanego. Przegląd Budowlany, nr 11, 2010.

6. Biliński T.: Środowisko naturalne a rewitalizacja obszarów miejskich. Renowacja budynków i modernizacja obszarów zabudowanych. Uniwersytet Zielonogórski, 2009.

7. Drążkiewicz A.: Unia dofinansuje modernizację. Builder Biznes Budownictwo Architektura, czerwiec 2014, s. 28-29.

8. Kopietz-Unger J.: Energetyczny Audyt Miejski - potrzeby, założenia, schemat. Przegląd Budowlany, nr 12, 2011.

9. Ostańska A.: Model energetycznego audytu miejskiego jako instrument stużący efektywnemu oszczędzaniu energii w mieście. Przegląd Budowlany, nr 10, 2014, s. 14-19.

10. List otwarty do Prezesa Rady Ministrów Donalda Tuska. Warszawa, 8 lipca 2014. Domy Spółdzielcze, sierpień 2014.

11. Rozporzadzenie Ministra Infrastruktury i Rozwoju w sprawie metodologii obliczania charakterystyki energetycznej budynku i lokalu mieszkalnego lub części budynku stanowiącej samodzielną całość techniczno-użytkową oraz sposobu sporządzania wzorów świadectw charakterystyki energetycznej (Dz. U. z 2014, poz. 888).

12. Rozporzadzenie Ministra Transportu, Budownictwa i Gospodarki Morskiej z dnia 5 lipca 2013. w sprawie warunków technicznych, jakim powinny odpowiadać budynki i ich usytuowanie (Dz. U. z 2013 r., poz. 926. 


\section{PROGRAMOWANIE REWITALIZACJI OBSZARÓW MIEJSKICH}

\section{Streszczenie}

W procesie inwestycyjno-budowlanym szczególne znaczenie ma programowanie. Jego wpływ na koszty, czas realizacji i ogólnie na jakość rozwiązania projektowego jest przeogromny. Tymczasem w praktyce, za wyjątkiem obiektów użyteczności publicznej lub innych obiektów budowlanych szczególnego znaczenia, niewiele uwagi poświęca się temu etapowi prac przedprojektowych. W efekcie wyniki działalności inwestycyjnobudowlanej są niezadawalające. Dlatego też temu problemowi poświęcono tę publikację. W publikacji omówiono szczegółowo zagadnienie programowania przedsięwzięć rewitalizacyjnych obszarów miejskich, podkreślając bardzo jego znaczenie społecznogospodarcze. Dla zobrazowania złożoności programowania przedsięwzięć rewitalizacyjnych omówiono istotne czynniki społeczne, ekonomiczne, technicznoorganizacyjne, jak udział społeczeństwa, reorganizacja i rewaloryzacja zagospodarowania przestrzeni, racjonalizacja użytkowania energii, organizacja i zarządzanie procesami rewitalizacyjnymi, postęp techniczny. W podsumowaniu pracy podkreślono, że dla podwyższenia jakości życia mieszkańców miast, dla ochrony materialnego dziedzictwa narodowego nieodzowna jest ciągle prowadzona rewitalizacja kolejnych obszarów miasta.

Słowa kluczowe: rewitalizacja, programowanie, odnowa miast

Editor received the manuscript: 09.02.2015 
pusta 